\title{
Comparison of body size, relative growth and size at onset sexual maturity of $U c a$ uruguayensis (Crustacea: Decapoda: Ocypodidae) from different latitudes in the south-western Atlantic
}

\author{
GUSTAVO LUIS HIROSE ${ }^{1}$, VIVIAN FRANSOZO ${ }^{3}$, CAROLINA TROPEA ${ }^{4,5}$, LAURA S. LÓPEZ-GRECO ${ }^{4,5}$ \\ AND MARIA LUCIA NEGREIROS-FRANSOZO ${ }^{2}$ \\ ${ }^{1}$ Departamento de Biologia, Universidade Federal de Sergipe, SE, Brazil, ${ }^{2}$ NEBECC, Departamento de Zoologia, IBB, \\ UNESP, Botucatu, SP, Brazil, ${ }^{3}$ Instituto Federal Baiano, Campus de Santa Inês, Santa Inês, BA, Brazil, ${ }^{4}$ Biology of Reproduction \\ and Growth in Crustaceans, Departamento de Biodiversidad y Biología Experimental, FCEN, Universidad de Buenos Aires, \\ Argentina, ${ }^{5}$ IBBEA-CONICET, Argentina
}

\begin{abstract}
Some crustaceans show variations of their reproductive biology within their geographical distribution, and knowledge about such variations is important for the comprehension of their reproductive adaptations. This study compared two populations of the fiddler crab Uca uruguayensis from two locations on the south-western Atlantic coast: Ubatuba Bay, São Paulo, Brazil and Samborombón Bay, Buenos Aires, Argentina. The population features analysed were the body size variation (carapace width $=C W$ ) and the size at the onset of sexual maturity $(S O M)$ in order to test the hypothesis that the size at SOM, should be the same in relative terms (RSOM), independently of the latitudinal position. In the Brazilian population the CW ranged from 4.18 to $11.60 \mathrm{~mm}$ for males and 3.90 to $9.80 \mathrm{~mm}$ for females, and in the Argentinean population from 3.60 to $14.10 \mathrm{~mm}$ for males and 2.85 to $12.00 \mathrm{~mm}$ for females. In the Brazilian population the SOM was $7.1(R S O M=0.58)$ and $5.9 \mathrm{~mm} C W$ $(R S O M=0.57)$ for males and females, respectively, and in the Argentinean population it was $7.0(R S O M=0.42)$ and $6.75 \mathrm{~mm} \mathrm{CW}(R S O M=0.53)$ for males and females, respectively. This fact is probably related to a great plasticity in the life history features of Uca uruguayensis under different environmental conditions.
\end{abstract}

Keywords: latitudinal, variation, fiddler crab, crab size, allometry, Brazil, Argentina

Submitted 18 May 2012; accepted 11 June 2012; first published online 31 October 2012

\section{INTRDDUCTIDN}

Fiddler crabs of the genus Uca Leach, 1814 (family Ocypodidae) occur worldwide in the tropics and subtropics. Along the south-western Atlantic coast, ten species of fiddler crabs live on the muddy bottom of intertidal zones of bays and estuaries (Crane, 1975; Melo, 1996). In particular, Uca uruguayensis Nobili (1901) is distributed from Rio de Janeiro, Brazil to Mar Chiquita, Argentina (Melo, 1996); occasionally, a few specimens can be found in locations farther south such as Puerto Quequén, Argentina (Boschi, 1964; Jordá \& Roccatagliata, 2002; Roccatagliata \& Jordá, 2002).

During the life cycle of a typical brachyuran crab, gradual or abrupt changes might occur in the shape of particular body parts and body parts whose relative size commonly change during ontogeny include the chelipeds, abdomen

Corresponding author:

M.L. Negreiros-Fransozo

Email: mlnf@ibb.unesp.br and pleopods. These changes are typically under endocrine control, and are related to reproductive maturation, which distinguishes the juvenile from the adult phase (Hartnoll, 1969).

The size at the onset sexual maturity (SOM) is regularly determined using allometric techniques and is useful for studies on aspects of reproduction (Vaninni \& Gherardi, 1988; Sampedro et al., 1999; Corgos \& Freire, 2006). For instance, the morphological sexual maturity of the fiddler crab Uca cumulanta, studied by Pralon \& NegreirosFransozo (2008), showed a similar pattern to those known for other fiddler crabs, with males attaining a larger size at the SOM than females (Negreiros-Fransozo et al., 2003; Cardoso \& Negreiros-Fransozo, 2004).

Body size is probably the most important quantitative trait of an individual. It deeply affects virtually all physiological (e.g. metabolic rate) and fitness traits (e.g. fecundity or mating success), producing strong but not necessarily well understood allometric relationships within and among organisms (McNab, 1971; Blanckenhorn \& Demont, 2004). An increase in body size with latitude is known as Bergmann's rule (Blackburn et al., 1999). The mechanisms causing this pattern are yet to be completely understood and they relate 
to different hypotheses (McNab, 1971; Blackburn et al., 1999; Blanckenhorn \& Demont, 2004).

Apparently Bergmann's rule can be applied to decapod crustaceans. Intraspecific studies have a tendency to show that larger bodies occupy higher latitudes with a correlated increase in the size at SOM (Jones \& Simons, 1983; Hines, 1989; Lardies \& Castilla, 2001; Castilho et al., 2007). However, in theory, SOM should be reached by both male and female crabs at the same relative size, when they attain a specific percentage of their final body size at each locality (Charnov, 1990). This is evident in pandalid shrimps, where their relative size at SOM is not affected by latitude and invariably occurs at the same relative size, oscillating slightly between 0.54 and 0.56 in different localities and in seasons within localities (Charnov, 1990).

The fiddler crab $U$. uruguayensis from Brazilian and Argentinean coasts has not been studied in detail. Only a few aspects of their population biology and the occurrence of parasites have been reported (Spivak et al., 1991; Roccatagliata \& Jordá, 2002; Costa et al., 2006). The present study compared SOM between two populations of $U$. uruguayensis from different geographical regions (Brazil and Argentina). We test the hypothesis that SOM should not be affected by latitude and remains the same relative to maximum body size attained by the species at different latitudes. Also, we compared these populations to detect latitudinal effects on the relative growth pattern and the size attained by specimens.

\section{MATERIALS AND METHDDS}

Both studied populations inhabit mud and sand bottom environments. In Brazil, the crabs were collected from a mangrove area in Indaiá River, Ubatuba $\left(23^{\circ} 24^{\prime} \mathrm{S} 45^{\circ} 03^{\prime} \mathrm{W}\right)$, São Paulo, Brazil. In Argentina, the crabs were collected from a mud bank located on the mouth of a tidal creek at Punta Rasa, Samborombón Bay $\left(36^{\circ} 19^{\prime} \mathrm{S} 56^{\circ} 47^{\prime} \mathrm{W}\right)$, Buenos Aires. Both sites are estuarine environments with very fine sediment and gentle slope. In Brazil, water temperature ranged from $15.1^{\circ} \mathrm{C}$ (winter) to $27.6^{\circ} \mathrm{C}$ (summer), and salinity from o to $32 \%$ (Colpo et al., 2011). In Argentina, water temperature ranged from $11^{\circ} \mathrm{C}$ (winter) to $30^{\circ} \mathrm{C}$ (summer), and salinity from 18.6 to $28 \%$ (Guerrero et al., 1997).

Sampling was conducted during each month for one year at both localities, from January to December 2006 at Ubatuba, and from February 1995 to March 1996 at Argentina. In each area, crabs were captured manually by two collectors working for 30 minutes each, during low-tide periods (midintertidal) during spring tides, covering an area of $1000 \mathrm{~m}^{2}$ each month. Each collector excavated the bottom searching for the burrows and crabs inside these refuges. The use of quadrats or transects for measuring crab abundance is not appropriate in this species. Uca uruguayensis dwell among plant roots and crabs are difficult to spot in this heterogeneous habitat. In the laboratory, each specimen was sexed and the following body dimensions were measured with a digital caliper $(0.01 \mathrm{~mm})$ : carapace width $(\mathrm{CW})$; length of the propodus of the major cheliped (PL); and abdomen width, measured between the fourth and fifth somites (AW). The allometric analysis of these structures in U. uruguayensis followed that described by Benetti \& Negreiros-Fransozo (2004), Cardoso
\& Negreiros-Fransozo (2004) and Castiglioni \& NegreirosFransozo (2004) for other fiddler crab species.

\section{Size comparison}

The mean size of CW of $U$. uruguayensis was compared between the sexes and localities as well as the interaction between these two factors, using a factorial analysis of variance (two-way analysis of variance (ANOVA), sex/localities as fixed factors) (Zar, 2010). Data were log transformed for all comparisons, but the variances remained heterogeneous (Levene $P<0.01$ ). This procedure is considered appropriate because of the large number of samples and considering that the ANOVA test is robust enough to stand considerable departures from its theoretical assumptions (Zar, 2010). The size of ovigerous females was compared between populations by a non-parametric Mann-Whitney U-test (Zar, 2010) because of low sample size.

\section{Allometric growth comparison}

The relative growth analysis of the crab dimensions was based on the allometric equation (Huxley, 1950): $y=a C W^{b}$, in which $y=$ dimension (body structure), $\mathrm{b}=$ slope, which represents the relative growth rate of the body structure, and $\mathrm{a}=$ line intercept in the $y$ axis. The parameters of the equation describing the relationship between the different variables were estimated by a linear regression on the log-log transformed morphometric data, i.e. the linearized equation $\left(\ln y=\ln a+b^{*} \ln x\right)$. To determine whether the relationship deviates from linearity $(b>1-$ exponential increase; $b<1-$ exponential decrease; $b=1-$ isometry), a $t$-test was used to examine whether the estimated slope $b$ deviates from the expected slope of unity. If the body structure of the crabs grows more or less proportionally with a unit increase in size, then the slope should be greater or smaller than the unity, respectively (Hartnoll, 1978; Baeza \& Asorey, 2012).

\section{Size at onset of maturity (SOM)}

In order to estimate the SOM, males were first grouped into age categories according to the relationship between CW and PL. Similarly, females were first grouped into age categories according to the relationship between CW and AW. Next, a K-means non-hierarchical clustering analysis was performed. This clustering analysis distributes the data in groups of numbers previously established by an iterative process that minimizes the variance within groups and maximizes it among them. The result of the classification (K-means) was refined using discriminant analysis. This statistical methodology was based on Sampedro et al. (1999) and Corgos \& Freire (2006).

If the CW overlapped between young and adult age categories, the SOM was determined as the CW at which $50 \%$ of the specimens showed morphometric relationships that characterized the adult condition (W 50\%). This value was obtained by logistic function interpolation $\left(\mathrm{AP}=\mathrm{a} /\left(1+\mathrm{be}^{-\mathrm{Cx}}\right)\right)$ adjusted to the data for adult proportion (AP) versus size-classes $(0.5 \mathrm{~mm})(\mathrm{CW})$. After crabs were grouped by age, the data were submitted to analysis of covariance (ANCOVA, $\alpha=0.05$ ), in order to test the linear and angular coefficients between groups (adult and juveniles) and between populations 
Table 1. Uca uruguayensis (Nobili, 1901). Descriptive statistics and size at the onset of sexual maturity (SOM) of each studied population.

\begin{tabular}{llllllll}
\hline Species & Locality & Sex & N & CW Min. & CW Max. & CW Mean \pm SD & SOM \\
\hline Uca uruguayensis & Samborombón, Argentina $\left(36^{\circ} \mathrm{S}\right)$ & Male & 259 & 3.60 & 14.10 & $10.18 \pm 1.75$ & 7.0 \\
& & Female & 300 & 2.85 & 12.00 & $9.36 \pm 1.22$ & 6.75 \\
& Ubatuba, Brazil $\left(23^{\circ} \mathrm{S}\right)$ & Male & 227 & 4.18 & 11.60 & $8.63 \pm 1.05$ & 7.1 \\
& & Female & 123 & 3.90 & 9.80 & $8.10 \pm 0.61$ & 5.9 \\
\hline
\end{tabular}

Max., maximum size; Min., minimum size; CW, carapace width (mm).

(Brazil and Argentina) (Zar, 2010). The goals of this analysis were to compare the relationships of relative growth:

- between adult and juvenile specimens, in order to detect differences occurring in ontogeny;

- between localities for each age category, in order to assess differences between populations.

To compare the results between these populations and also to compare them with other, previously studied populations, the relative size at onset of maturity (RSOM) was calculated using the following equation:

$$
\mathrm{RSOM}=\mathrm{SOM} / \mathrm{W}_{\infty},
$$

in which $\mathrm{W}_{\infty}$ is the asymptotic maximum size attained by crabs (Charnov, 1990).

As only the maximum individual sizes of each population were available, the asymptotic size was estimated by the empirical equation: $\mathrm{W}_{\infty}=\mathrm{CW}$ maximum/0.95 (Charnov, 1990).

\section{RESULTS}

\section{Size comparison}

Because several fiddler crab species live in the Brazilian mangroves, it is very difficult to identify specimens (at species level) smaller than $3.5 \mathrm{~mm}$ of $\mathrm{CW}$ approximately. The $\mathrm{CW}$ of the specimens larger than $3.5 \mathrm{~mm}$ CW from the Brazilian population ( 227 males and 123 females) ranged from 4.18 to $11.60 \mathrm{~mm}$ for males and from 3.90 to $9.80 \mathrm{~mm}$ for females (Table 1; Figure. 1). Ovigerous females $(\mathrm{N}=8 \mathrm{crabs})$ were observed in the Brazilian population, and measured from 5.7 to $8.47 \mathrm{~mm}$ of $\mathrm{CW}$ (mean size $=7.3 \pm 1.0 \mathrm{~mm}$ ). In Argentinean estuaries the only fiddler crab species is Uca uruguayensis, and therefore all fiddler crabs found were considered to be the target species. The $\mathrm{CW}$ of the Argentinean specimens ( 259 males and 300 females) ranged from 3.60 to $14.10 \mathrm{~mm}$ for males and from 2.85 to $12.00 \mathrm{~mm}$ for females (Table 1; Figure. 1). Ovigerous females $(\mathrm{N}=33 \mathrm{crabs})$ from the Argentinean population measured from 6.85 to $11.35 \mathrm{~mm}$ CW (mean size $=9.08 \pm 1.28 \mathrm{~mm}$ ). The mean size of this fiddler crab for both localities differed significantly between sexes, with males attaining larger body sizes than females (Table 2). The mean size of each sex of U. uruguayensis also differed between the populations with both males and females being larger in the Argentinean than in the Brazilian populations (Table 2).

With respect to ovigerous females, the specimens from Argentina $(\mathrm{N}=33 ; 9.08 \pm 1.28 \mathrm{~mm} \mathrm{CW})$ are larger than those from Brazil $(\mathrm{N}=8 ; 7.3 \pm 1.0 \mathrm{~mm} \mathrm{CW})(U=33.5$, $P<0.05)$.

\section{Allometric growth comparison}

Males of both populations showed positive allometry in the relationship PL versus CW for all age categories, with higher
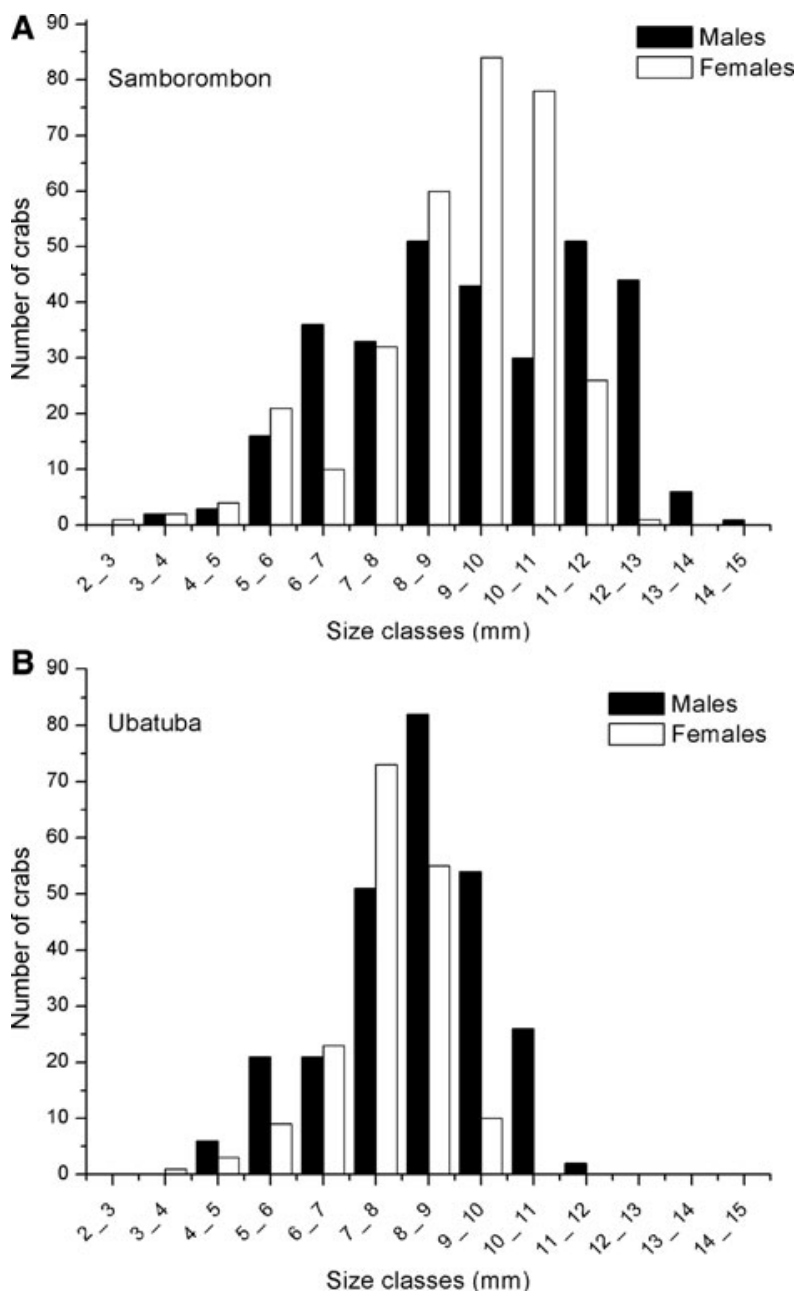

Fig. 1. Uca uruguayensis (Nobili, 1901): size-frequency distribution of each studied fiddler crab population (A) Argentina and (B) Brazil, carapace width $(\mathrm{mm})$ used as the body size representation.

Table 2. Results of two-way analysis of variance for the carapace width between sex and localities.

\begin{tabular}{lllrr}
\hline Effect & df & ms & \multicolumn{1}{c}{ F } & \multicolumn{1}{c}{$\boldsymbol{P}$ level } \\
\hline Sex & 1 & 0.848 & 18.20 & $<0.001$ \\
Locality & 1 & 4.600 & 98.80 & $<0.001$ \\
Sex versus locality & 1 & 0.069 & 1.48 & 0.224 \\
\hline
\end{tabular}

df, degrees of freedom; ms, mean square. 
Table 3. Uca uruguayensis (Nobili, 1901). Allometric analysis of transformed morphometric data (ln) using the carapace width as independent variable, and analysis of covariance (ANCOVA) between juveniles and adults for each relationship analysed.

\begin{tabular}{|c|c|c|c|c|c|c|c|c|c|c|}
\hline \multirow[t]{2}{*}{ Relationship } & \multirow[t]{2}{*}{ Category } & \multirow[t]{2}{*}{$\mathbf{N}$} & \multirow[t]{2}{*}{ Intercept $(\ln )$} & \multirow[t]{2}{*}{ slope } & \multirow[t]{2}{*}{$\mathbf{r}^{2}$} & \multirow[t]{2}{*}{$\mathrm{T}(\mathrm{b}=\mathbf{1})$} & \multirow[t]{2}{*}{$\begin{array}{l}\text { Regression } \\
P \text { value }\end{array}$} & \multirow[t]{2}{*}{ Allometry } & \multicolumn{2}{|c|}{$\begin{array}{l}\text { ANCOVA } P \\
\text { value }\end{array}$} \\
\hline & & & & & & & & & $a$ & $b$ \\
\hline \multirow[t]{4}{*}{ PL versus $C W$ males } & $\mathrm{AJ}$ & 63 & -2.06 & 2.05 & 0.92 & 13.5 & $<0.05$ & + & - & $<0.01$ \\
\hline & AA & 259 & -1.42 & 1.75 & 0.94 & 30 & $<0.05$ & + & & \\
\hline & $\mathrm{BJ}$ & 56 & -1.35 & 1.74 & 0.75 & 5.48 & $<0.05$ & + & $<0.01$ & 0.57 \\
\hline & $\mathrm{BA}$ & 207 & -1.026 & 1.68 & 0.85 & 14.16 & $<0.05$ & + & & \\
\hline \multirow[t]{4}{*}{$\mathrm{AW}$ versus $\mathrm{CW}$ females } & $\mathrm{AJ}$ & 53 & -1.96 & 1.50 & 0.92 & 8.47 & $<0.05$ & + & - & $<0.01$ \\
\hline & AA & 290 & -1.38 & 1.29 & 0.85 & 9.06 & $<0.05$ & + & & \\
\hline & BJ & 13 & -1.27 & 1.22 & 0.51 & 0.66 & $<0.05$ & $=$ & $<0.01$ & 0.59 \\
\hline & $\mathrm{BA}$ & 161 & -0.98 & 1.12 & 0.73 & 2.4 & $<0.05$ & + & & \\
\hline
\end{tabular}

CW, carapace width; PL, propodus length; AW, abdomen width; AJ, juvenile specimens from Argentina; AA, adult specimens from Argentina; BJ, juvenile specimens from Brazil; BA, adult specimens from Brazil; +, positive allometry; -, negative allometry; =, isometry.

values for juveniles. When compared between populations, Argentinean males showed higher allometric coefficients for both juvenile and adult age categories $(1.75 ; 2.05$ and 1.74 ; 1.68 for juveniles and adults of Argentina and Brazil, respectively).

For females, the relationship AW versus CW showed the same pattern found in males, with higher allometric coefficients for the Argentinean population in both age categories (1.50; 1.29 and $1.22 ; 1.12$ for juveniles and adults of Argentina and Brazil, respectively). Juvenile Brazilian females showed isometry even with a positive allometric coefficient $(b=1.22)$, this probably occurred due to the small sample size $(\mathrm{N}=13)$.

The ANCOVA of transformed morphometric data $(\ln )$ revealed a statistically significant difference between the demographic categories (juveniles and adults) (Table 3 ) and between the populations $(P<0.05)$ (Table 4$)$.

\section{Size at onset of maturity (SOM)}

An overlap of the size at maturity was found for males from the Brazilian population and for females from the Argentinean population. The SOM (W 50\%) for the relationship PL versus CW for males from the Brazilian population was $7.1 \mathrm{~mm}$ ranging from 6.93 to $8.12 \mathrm{~mm}$, while for males from Argentina the SOM was estimated at $7.0 \mathrm{~mm} \mathrm{CW}$ (Table 1; Figures 2 \& 3). In females, the SOM for the relationship AW versus CW was $5.9 \mathrm{~mm}$ for the Brazilian population, while for the Argentinean population it was $6.75 \mathrm{~mm}$
(W 50\%), ranging from $6.2 \mathrm{~mm}$ to $7.5 \mathrm{~mm} \mathrm{CW}$ (Table 1; Figures 2 \& 3).

The RSOM was very similar for males and females from Brazil ( 0.58 and 0.57 for males and females, respectively) with a difference of $1 \%$ between the sexes. For males and females from Argentina, the difference between the RSOM ( 0.42 and 0.53 for males and females respectively) was greater (11\%). Comparing between populations, lower values were found for crabs in Argentina, with a difference of $16 \%$ for males. For females the difference was small (3\%).

\section{DISCUSSIDN}

\section{Body size and sexual dimorphism}

The size of the fiddler crab Uca uruguayensis showed latitudinal cline, corroborating the Bergmann's rule, with the smaller crabs occurring at the lower latitude (Brazil) and larger crabs at the higher latitude (Argentina). There is much debate as to whether the ectothermic Bergmann cline is adaptative and/or a mere consequence of physiological processes (Blanckenhorn \& Demont, 2004). However, at the moment, there is no general theory available demonstrating the adaptive nature of Bergmann clines (Atkinson \& Sibly, 1997; Blanckenhorn \& Demont, 2004). In contrast, physiologists emphasize different mechanisms to explain the Bergmann's rule. These mechanisms are normally related to different thermal exposures that could result in different physiological costs at the cellular level (Stillman \& Somero, 200o). The theoretical basis for

Table 4. Uca uruguayensis (Nobili, 1901). Analysis of covariance between populations for each demographic category.

\begin{tabular}{|c|c|c|c|c|c|c|c|}
\hline \multirow[t]{2}{*}{ Relationship } & \multirow[t]{2}{*}{ Factor (Group) } & \multicolumn{2}{|c|}{ Argentina } & \multicolumn{2}{|l|}{ Brazil } & \multirow[t]{2}{*}{$\mathbf{F}$} & \multirow[t]{2}{*}{$P$} \\
\hline & & Par. (ln) & value & Par. (ln) & Value & & \\
\hline \multirow[t]{4}{*}{ PL versus $C W$ males } & \multirow[t]{2}{*}{ Juvenile } & $a$ & -2.06 & $a$ & -1.35 & - & - \\
\hline & & $b$ & 2.05 & $b$ & 1.74 & $5 \cdot 30$ & $<0.05$ \\
\hline & \multirow[t]{2}{*}{ Adult } & $a$ & -1.42 & $a$ & -1.026 & - & - \\
\hline & & $b$ & 1.75 & $b$ & 1.68 & 918 & $<0.01$ \\
\hline \multirow[t]{4}{*}{ AW versus $C W$ females } & \multirow[t]{2}{*}{ Juvenile } & $a$ & -1.96 & $a$ & -1.27 & 46.50 & $<0.01$ \\
\hline & & $b$ & 1.50 & $b$ & 1.22 & 1.32 & 0.25 \\
\hline & \multirow[t]{2}{*}{ Adult } & $a$ & -1.38 & $a$ & -0.98 & - & - \\
\hline & & $b$ & 1.29 & $b$ & 1.12 & $7 \cdot 30$ & $<0.01$ \\
\hline
\end{tabular}

CW, carapace width; PL, propodus length; AW, abdomen width; Par, parameter. 

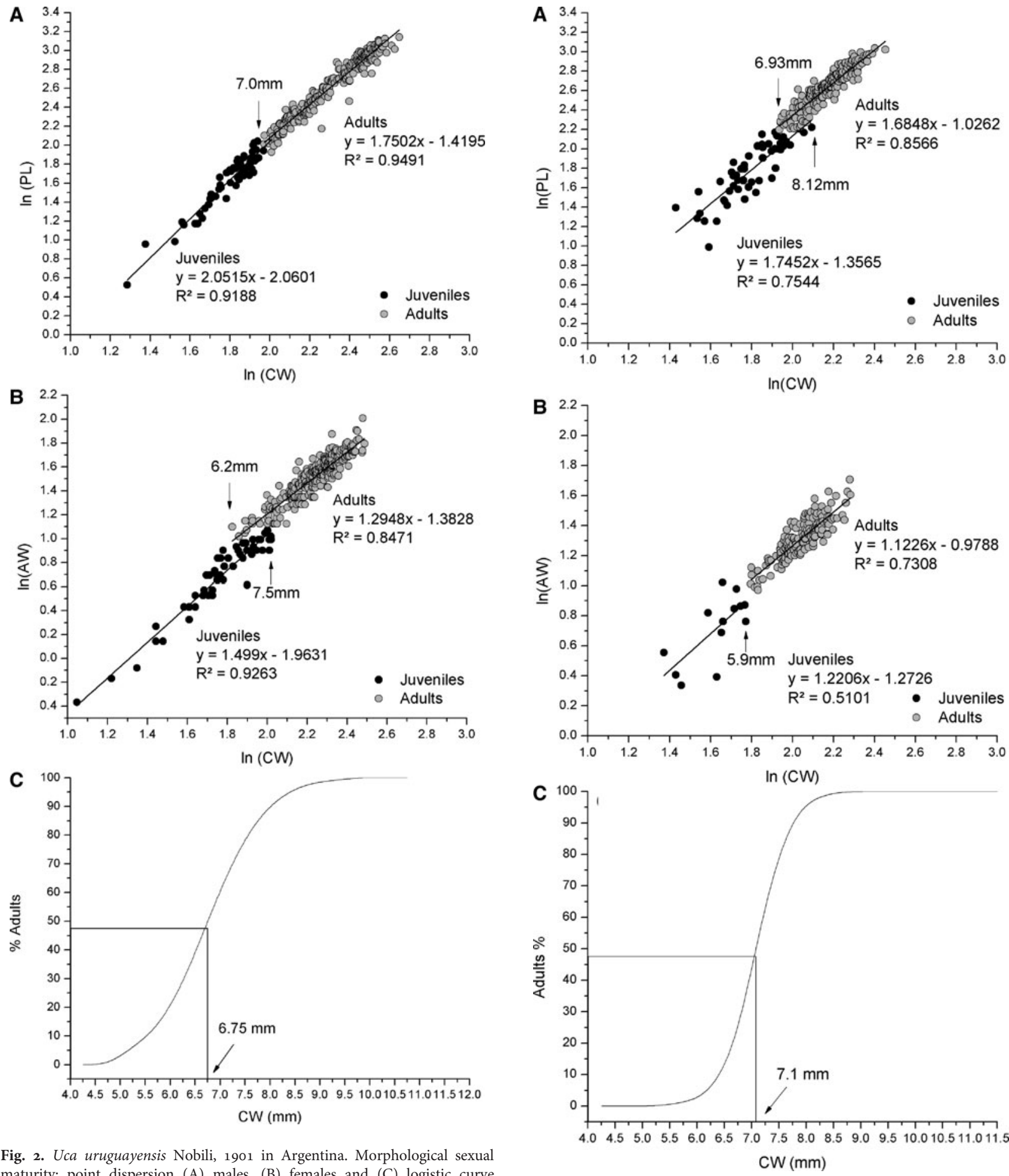

Fig. 2. Uca uruguayensis Nobili, 1901 in Argentina. Morphological sexual maturity: point dispersion (A) males, (B) females and (C) logistic curve (carapace width 50\%) for females.

clarifying the hypotheses and mechanisms involved in the Bergmann's rule was previously discussed by Blackburn et al. (1999) and Blanckenhorn \& Demont (2004).

Males were larger than females in both populations. This is commonly found for brachyurans (Warner, 1967; Benetti \& Negreiros-Fransozo, 2003; Johnson, 2003; Luppi et al., 2004; Litulo, 2005; Hirose et al., 2008) and is probably related to sexual selection based on the reproductive behaviour of these crabs. In fiddler crabs, males have one of their two

Fig. 3. Uca uruguayensis Nobili, 1901 in Brazil. Morphological sexual maturity: point dispersion (A) males, (B) females and (C) logistic curve (carapace width $50 \%$ ) for males.

chelipeds greatly enlarged. It lost its feeding function and is used in both fighting and visual displaying (waving), which consists of a rhythmic elevation and lowering of the major chelae in order to attract the females into the male's burrow during the breeding season (Crane, 1966, 1975; Yamaguchi, 1977; Latruffe et al., 1999). The CW of males of this species is usually correlated with their claw size (Hyatt \& Salmon, 
1978) and, consequently, larger males can have an advantage in male-male competition. Larger body and claw may also have an adaptive value in mate attraction, where an enlarged and conspicuous claw would provide an advantage as it would be more easily detected and/or attractive to the wandering female (Oliveira \& Custódio, 1998).

An extended period of somatic growth and/or a greater moult increment may also reflect differences in body size between males and females. The energy allocated to reproduction should be proportionally higher in females, because more energy is needed for the production of oocytes than that of spermatocytes, and thus females can interrupt or reduce their somatic growth while they are incubating eggs (Alunno-Bruscia \& Sainte-Marie, 1998; Hartnoll, 2006). Slower growth can also reflect a reduced energy intake because of feeding restrictions. In females, a more general phenomenon is a restricted feeding habit during incubation. A further limitation on the growth of reproducing females is that they cannot moult while incubating eggs (Hartnoll, 2006).

Males of both populations, showed a higher allometric coefficient value (b) for the cheliped, during the juvenile phase. This may be a very important growth strategy and might be a response, in part, to the differences in the relative size of morphological sexual maturity for males between the populations. Behaviour in this genus is predominantly visual (Crane, 1975), and rapid development of the chelipeds may also ensure that a male could more rapidly and effectively participate in reproductive processes, and interact with other males for territory and/or food (Christy, 1978, 1983; Christy \& Salmon, 1984; Backwell et al., 2000). Large claws and the waving activity of males are important criteria for mate selection and it is primarily directed at receptive females (Oliveira \& Custódio, 1998; Latruffe et al., 1999).

There was a marked difference between the sexes with respect to the abdomen. In females, the abdomen growth showed high values of positive allometry. This growth pattern is related to the protection of the gonopores and egg mass during incubation and to the increase in the incubation capacity (Hartnoll, 1982).

Both populations showed a similar growth pattern, with positive allometric growth (see Table 2, and Figures 2 \& 3). However, within the Argentinean population, a higher allometric coefficient (b) was found for both sexes, mainly in juveniles. This could indicate different strategies for growth and reproduction between populations from different latitudes. An increase in the allometric growth coefficient of the secondary sexual appendages could anticipate the relative size at the onset sexual maturity (or RSOM), and consequently change the longevity and the life-time investment in reproduction (Anger \& Moreira, 1998).

\section{Morphological sexual maturity}

The size at onset of the sexual maturity (SOM) of the two populations was estimated and compared based on the allometric technique. SOM was very similar for both (Brazilian males $=7.1 \mathrm{~mm}$; Brazilian females $=5.9 \mathrm{~mm}$; Argentinean males $=7.0 \mathrm{~mm}$; Argentinean females $=6.75 \mathrm{~mm} \mathrm{CW}$ ). Considering the small number of juvenile Brazilian females used in the analysis of maturity, a bias should be expected. However, when comparing the size of the smallest ovigerous female $(5.7 \mathrm{~mm} \mathrm{CW})$ with the estimated size at morphological sexual maturity $(5.9 \mathrm{~mm} \mathrm{CW})$, it becomes clear that the values are quite close, and therefore we consider the estimate valid.

The relative size of SOM (RSOM) was lower for males and females of $U$. uruguayensis from the higher latitude $\left(36^{\circ} \mathrm{S}\right)$ ( $\mathrm{RSOM}=0.42$ and 0.53 , respectively) than for those from the lower latitude $\left(23^{\circ} \mathrm{S}\right)(\mathrm{RSOM}=0.58$ and 0.57 , respectively). These differences found in the RSOM are not surprising since the allometric growth coefficient of the secondary sexual appendages was higher in the Argentinean than in the Brazilian population. These results reinforce the hypothesis proposed by Pralon \& Negreiros-Fransozo (2008) that this parameter is not a constant among the genus Uca. Conde \& Díaz (1992) suggest that the intraspecific variation in the relative size at the SOM can be a reflex of a great plasticity of the species under different environmental conditions.

The correlations of the body size with latitude of $U$. uruguayensis demonstrated by a latitudinal cline, reinforces the ecogeographical rule initially proposed by Bergmann. This pattern is common in many arthropods, although the underlying cause of the Bergmann rule to date remains a mystery (Blanckenhorn \& Demont, 2004). Regarding the relative size at which $U$. uruguayensis attained sexual maturity in different habitats, our results contrast with the null hypothesis tested. This is probably because the life history features of $U$. uruguayensis are very plastic under different environmental conditions, i.e. different levels of productivity and stress, or the presence, mainly in mangrove areas, of large amounts of growth-inhibiting substances (e.g. polyphenols derived from tannins of halophyte plants) (Power \& Bliss, 1983; Rodríguez, 1987; Díaz \& Conde, 1988, 1989; Conde \& Díaz, 1989; Negreiros-Fransozo, 2002). Other studies comparing the population parameters at different latitudes are needed for a better understanding of the life-history variants of the South Atlantic fiddler crabs.

\section{ACKNDWLEDGEMENTS}

We thank the CNPq (Conselho Nacional de Desenvolvimento Científico e Tecnológico) and the Graduate Course in Zoology at the 'Instituto de Biociências, Universidade Estadual Paulista' for financial support for this research and also the visit of Laura S. López-Greco from Argentina to Brazil (Prosul \#490208/2005-3). We also thank Drs Daniel Roccatagliata and Martín Torres Jordá from the 'Facultad de Ciencias Naturales y Exactas, Universidad de Buenos Aires' for donation of Argentinean specimens and Dr Janet W. Reid for improving our English. All sampling in Brazil was carried out according to state and federal laws regulating wildlife collection.

\section{REFERENCES}

Alunno-Bruscia M.B. and Sainte-Marie B. (1998) Abdomen allometry, ovary development, and growth of female snow crab, Chionoecetes opilio (Brachyura, Majidae), in the northwestern Gulf of St Lawrence. Canadian Journal Fisheries and Aquatic Sciences 55, $459-477$.

Anger K. and Moreira G.S. (1998) Morphometric and reproductive traits of tropical caridean shrimps. Journal of Crustacean Biology 18, $823-838$. 
Atkinson D. and Sibly R.M. (1997) Why are organisms usually bigger in colder environments? Making sense of a life history puzzle. Trends in Ecology and Evolution 12, 235-239.

Backwell P.R.Y., Christy J.H., Telford S.R., Jennions M.D. and Passmore N.I. (2000) Dishonest signalling in a fiddler crab. Proceedings of the Royal Society of London, Series B 267, 1-6.

Baeza J.A. and Asorey C. (2012) Testing the role of male-male competition in the evolution of sexual dimorphism: a comparison between two species of porcelain crabs. Biological Journal of the Linnean Society 105, 548-558.

Benetti A.S. and Negreiros-Fransozo M.L. (2003) Madurez sexual morfológica Del cangrejo Uca burgersi Holthuis, 1967 (Brachyura, Ocypodidae) de uma área de manglar subtropical de Brasil. Revista Universidad y Ciencia 19, 9-16.

Benetti A.S. and Negreiros-Fransozo M.L. (2004) Relative growth of Uca burgersi (Crustacea, Ocypodidae) from two mangroves in the southeastern Brazilian coast. Iheringia-Série Zoologia 94, 67-72.

Blackburn T.M., Gaston K.J. and Loder N. (1999) Geographic gradients in body size: a clarification of Bergmann's rule. Diversity and Distributions 5, 165-174.

Blanckenhorn W.U. and Demont M. (2004) Bergmann and converse Bergmann latitudinal cline in arthropods: two ends of a continuum? Integrative and Compartive Biology 44, 413-424.

Boschi E.E. (1964) Los crustáceos decápodos Brachyura del litoral bonaerense (R. Argentina). Boletín del Instituto de Biología Marina, Mar del Plata, Argentina 6, 3-99.

Cardoso R.C.F. and Negreiros-Fransozo M.L. (2004) A comparison of the allometric growth in Uca leptodactyla (Crustacea: Brachyura: Ocypodidae) from two subtropical estuaries. Journal of the Marine Biological Association of the United Kingdom 84, 733-735.

Castiglioni D. da S. and Negreiros-Fransozo M.L. (2004) Comparative analysis of the relative growth of Uca rapax (Smith, 1870) (Crustacea, Ocypodidae) from two mangroves in São Paulo, Brazil. Revista Brasileira de Zoologia 21, 137-144.

Castilho A.L., Gavio M.A., Costa R.C. da, Boschi E.E., Bauer R.T. and Fransozo A. (2007) Latitudinal variation in population structure and reproductive pattern of the endemic South American shrimp Artemesia longinaris (Decapoda: Penaeoidea). Journal of Crustacean Biology 27, 548-552.

Charnov E.L. (1990) Relative size at the onset of maturity (RSOM) is an interesting number in crustacean growth (Decapoda, Pandalidae). Crustaceana 59, 108-109.

Christy J.H. (1978) Adaptive significance of reproductive cycles in fiddler crab Uca pugilator: a hypothesis. Science 199, 453-455.

Christy J.H. (1983) Female choice in the resource-defense mating system of the sand fiddler crab Uca pugilator. Behavioral Ecology and Sociobiology 12, 169-180.

Christy J.H. and Salmon M. (1984) Ecology and evolution of mating systems of fiddler crabs (Genus Uca). Biological Reviews 59, 483-509.

Colpo K.D., Negreiros-Fransozo M.L, Chacur M.M. and Guimarães F.J. (2011) Subtropical Brazilian mangroves as a refuge of crab (Crustacea: Decapoda) diversity. Biodiversity and Conservation 20, 3239-3250.

Conde J.E. and Díaz H. (1989) Productividad del hábitat e historias de vida del cangrejo de mangle Aratus pisonii (H. Milne Edwards) (Brachyura: Grapsidae). Boletín del Instituto Oceanográfico de la Universidad de Oriente 28, 113-120.

Conde J.E. and Díaz H. (1992) Variations in intraspecific relative size at onset of sexual maturity (SOM) in Aratus pisonii (H. Milne Edwards, 1837) (Crustacea, Decapoda, Grapsidae). Crustaceana 62, 214-216.
Corgos A. and Freire J. (2006) Morphometric and gonad maturity in the spider crab Maja brachydactyla: a comparison of methods for estimating size at maturity in species with determinate growth. ICES Journal of Marine Science 63, 851-859.

Costa T.M., Silva S.M.J. and Negreiros-Fransozo M.L. (2006) Reproductive pattern comparison of Uca thayeri Rathbun, 1900 and U. uruguayensis Nobili, 1901 (Crustacea, Decapoda, Ocypodidae). Brazilian Archives of Biology and Technology 49, 117-123.

Crane J. (1966) Combat, display and ritualization in fiddler crabs (Ocypodidae, genus Uca). Philosophical Transactions of the Royal Society B: Biological Sciences 251, 459-472.

Crane J. (1975) Fiddler crabs of the world. Ocypodidae: Genus Uca. Princeton, NJ: Princeton University Press, 736 pp.

Díaz H. and Conde J.E. (1988) On the food sources for the mangrove tree crab Aratus pisonii (Brachyura, Grapsidae). Biotropica 20, 348-350.

Díaz H. and Conde J.E. (1989) Population dynamics and life history of the mangrove crab Aratus pisonii (Brachyura: Grapsidae) in a marine environment. Bulletin of Marine Science 45, 148-163.

Guerrero R.A., Lasta C.A., Acha E.M, Mianzan H.W. and Framiñan M.B. (1997) Atlas hidrográfico del Río de La Plata. Buenos Aires and Montevideo: Comisión Administradora del Río de La Plata, Instituto Nacional de Investigación y desarrollo pesquero, 109 pp.

Hartnoll R.G. (1969) Mating in the Brachyura. Crustaceana 16, 162-181.

Hartnoll R.G. (1978) The determination of relative growth in Crustacea. Crustaceana 34, 281-292.

Hartnoll R.G. (1982) Growth. In Abele L.G. (ed.) The biology of Crustacea: embryology, morphology and genetics. New York: Academic Press, Inc., pp. 111-196.

Hartnoll R.G. (2006) Reproductive investment in Brachyura. Hydrobiologi 55, 31-40.

Hines A.H. (1989) Geographic variation in size at maturity in brachyuran crabs. Bulletin of Marine Science 45, 356-168.

Hirose G.L. and Negreiros-Fransozo M.L. (2008) Population biology of Uca maracoani Latreille 1802-1803 (Crustacea, Brachyura, Ocypodidae) on the south-eastern coast of Brazil. Pan-American Journal of Aquatic Sciences 3, 373-383.

Huxley J.S. (1950) Relative growth and form transformation. Proceedings of the Royal Society of London 137, 465-469.

Hyatt G.W. and Salmon M. (1978) Combat in the fiddler crabs Uca pugilator and U. pugnax: a quantitative analysis. Behaviour 65, 182-211.

Johnson P.T.J. (2003) Biased sex ratios in fiddler crabs (Brachyura, Ocypodidae): a review and evaluation of the influences of sampling method, size class, and sex specific mortality. Crustaceana 76 , 559-580.

Jones M.B. and Simons M.J. (1983) Latitudinal variation in reproductive characteristics of a mud crab, Helice crassa (Grapsidae). Bulletin of Marine Science 33, 656-670.

Jordá M.T. and Roccatagliata D. (2002) Population dynamics of Leidya distorta (Isopoda: Bopyridae) infesting the fiddler crab Uca uruguayensis at the Río de La Plata estuary, Argentina. Journal of Crustacean Biology 22, 719-727.

Lardies M.A. and Castilla J.C. (2001) Latitudinal variation in the reproductive biology of the commensal crab Pinnaxodes chilensis (Decapoda: Pinnotherdae) along the Chilean coast. Marine Biology 139, $1125-1133$.

Latruffe C., MacGregor P.K. and Oliveira R.F. (1999) Visual signalling and sexual selection in male fiddler crabs Uca tangeri. Marine Ecology Progress Series 189, 233-240. 
Litulo C. (2005) Breeding season of the hermit crab Dardanus deformis H. Milne Edwards, 1836 (Anomura, Diogenidae) in Maputo Bay, southern Mozambique. Journal of Natural History 39, 2137-2144.

Luppi T.A., Spivak E.D., Bas C.C. and Anger K. (2004) Molt and growth of an estuarine crab, Chasmagnathus granulatus (Brachyura: Varunidae), in Mar Chiquita coastal lagoon, Argentina. Journal of Applied Ichthyology 20, 333-344.

McNab B.K. (1971) On the ecological significance of Bergmann's rule. Ecology 52, 845-854.

Melo G.A.S. (1996) Manual de identificação dos Brachyura (caranguejos e siris) do litoral brasileiro. São Paulo: Plêiade/FAPESP Editora, 603 pp.

Negreiros-Fransozo M.L. (2002) Size variation in the grapsid crab Aratus pisonii (H. Milne-Edwards, 1837) among populations of different subtropical mangroves. In Escobar Briones E. and Alvarez F. (Orgs) Moddern approaches to the study of Crustacea. Volume 1. New York: Kluwer Academic/Plenum Publishers, pp. 183-188.

Negreiros-Fransozo M.L., Colpo K.D. and Costa T.M. (2003) Allometric growth in the fiddler crab Uca thayeri (Brachyura, Ocypodidae) from a subtropical mangrove. Journal of Crustacean Biology 23, 273-279.

Oliveira R.F. and Custódio M.R. (1998) Claw size, waving display and female choice in the European fiddler crab, Uca tangeri. Ethology Ecology \& Evolution 10, 241-251.

Power L.W. and Bliss D.E. (1983) Terrestrial adaptations. In Bliss D.E. (ed.) The biology of Crustacea: environmental adaptations. Volume 8. New York, Academic Press, pp. 271-333.

Pralon B.G.N. and Negreiros-Fransozo M.L. (2008) Relative growth and morphological sexual maturity of Uca cumulanta (Crustacea: Decapoda: Ocypodidae) from a tropical Brazilian mangrove population. Journal of the Marine Biological Association of the United Kingdom 88, 569-574.

Roccatagliata D. and Jordá M.T. (2002) Infestation of the fiddler crab Uca uruguayensis by Leidya distorta (Isopoda, Bopyridae) from the Río de La Plata estuary, Argentina. Journal of Crustacean Biology 22 $69-82$.
Rodríguez G. (1987) Structure and production in Neotropical mangroves. Trends in Ecology and Evolution 2, 264-267.

Sampedro M., González-Gurriarán E., Freire J. and Muiño R. (1999) Morphometry and sexual maturity in the spider crab Maja squinado (Decapoda: Majidae) in Galicia, Spain. Journal of Crustacean Biology 19, $578-592$.

Spivak E.D., Gavio M.A. and Navarro C.E. (1991) Life history and structure of the world's southernmost Uca population: Uca uruguayensis (Crustacea, Brachyura) in Mar Chiquita lagoon (Argentina). Bulletin of Marine Science 48, 679-688.

Stillman J.H. and Somero G.N. (2000) A comparative analysis of the upper thermal tolerance limits of eastern Pacific porcelain crabs, genus Petrolisthes: influences of latitude, vertical zonation, acclimation and phylogeny. Physiological and Biochemical Zoology 73, 200-2008.

Vaninni M. and Gherardi F. (1988) Studies on the pebble crab, Eriphia smithi MacLeay, 1838 (Xanthoidea, Menippidae): patterns of relative growth and population structure. Tropical Zoologist 1, 203-216.

Yamaguchi T. (1977) Studies on the handedness of the fiddler crab Uca lactea. Biological Bulletin. Marine Biological Laboratory, Woods Hole $152,424-236$.

Warner G.F. (1967) The life history of the mangrove tree crab Aratus pisonii. Journal of Zoology 53, 321-335.

and

Zar J.H. (2010) Biostatistical analysis. 5th edition. Upper Saddle River, NJ Prentice-Hall, 662 pp.

Correspondence should be addressed to:

M.L. Negreiros-Fransozo

NEBECC, Departamento de Zoologia

IBB, UNESP, Botucatu, SP, Brazil

email: mlnf@ibb.unesp.br 